\begin{tabular}{|c|c|}
\hline Title & Microscopic Observations of Freezing Phenomena in PEM Fuel Cells at Cold Starts \\
\hline Author(s) & Chikahisa, Takemi \\
\hline Citation & $\begin{array}{l}\text { Heat Transfer Engineering, 34(2-3), 258-265 } \\
\text { https://doi.org/10.1080/01457632.2013.703579 }\end{array}$ \\
\hline Issue Date & 2012-10-04 \\
\hline DOC URL & http:/hdl.handle.net/2115/53392 \\
\hline Rights & $\begin{array}{l}\text { This is an A uthor's A ccepted Manuscript of an article published in Heat Transfer Engineering, Volume 34, Issue 2-3, } \\
\text { pages 258 265, 2012, Copyright @ 2012 Taylor \& Francis, available online at: } \\
\text { http://www.tandfonline.com/10.1080/01457632.2013.703579. }\end{array}$ \\
\hline Type & article (author version) \\
\hline File Information & HTE34-2-3_258-265.pdf \\
\hline
\end{tabular}

Instructions for use 


\title{
Microscopic Observations of Freezing Phenomena \\ in PEM Fuel Cell at Cold Starts
}

\author{
Takemi Chikahisa ${ }^{1}$
}

${ }^{1}$ Graduate School of Engineering, Hokkaido University, Sapporo, Japan

Address correspondence to Professor Takemi Chikahisa, Graduate School of Engineering, Hokkaido University, N13, W8, Sapporo, Hokkaido, 060-8628, Japan. E-mail: takemi@eng.hokudai.ac.jp

Phone Number: (+81) 11706 6785, Fax Number: (+81) 117067889 


\section{ABSTRACT}

In Polymer electrolyte membrane fuel cells (PEMFCs), the generated water transfers from the catalyst layer to the gas channel through micro channels of different scales in a two phase flow. It is important to know details of the water transport phenomena to realize better cell performance, as the water causes flooding at high current density conditions and give rise to startup problems at freezing temperatures. The paper here, which was originally written for the keynote speech in the ICNMM conference in 2011, presents specifics of the ice formation characteristics in the catalyst layer and in the gas diffusion layer (GDL) with photos taken with an optical microscope and a CRYO-SEM. The observation results show that cold starts at $-10^{\circ} \mathrm{C}$ results in ice formation at the interface between the catalyst layer and the micro porous layer (MPL) of the GDL, and that at $-20^{\circ} \mathrm{C}$ most of the ice is formed in the catalyst layer. Water transport phenomena through the micro porous layer and GDL are also a matter of interest, because the role of the MPL is not well understood from the water management angle. The paper discusses the difference in the water distribution at the interface between the catalyst layer and the GDL arising from the presence of such a micro porous layer. 


\section{INTRODUCTION}

Polymer electrolyte membrane fuel cells (PEMFCs) are a promising candidate for automotive power sources and also for domestic power sources involving combined heat and power (CHP) generation. However, some aspects of PEMFCs need to be improved, and in cold regions startup at freezing temperatures is one such issue. The freezing of the water generated in PEMFCs induces an extreme deterioration of the cell performance, and there are aspects of this freezing phenomenon that are not fully elucidated or understood, yet. Another issue is water flooding at high current density conditions, which deteriorates efficiency and maximum power output due to the limitations on gas diffusion imposed by the accumulated water in the GDL (Gas Diffusion Layer). To better deal with this it is of great interest to establish the optimal structure of the GDL, the micro porous layers and the channel configurations, in order to avoid or at least diminish the effect of flooding and the undesirable freezing. All of these effects may be categorized as water transport phenomena in the layers of different types of micro channels.

The paper presents details of the freezing phenomena in fuel cells, which are different depending on temperatures. Then extended research of the observation method used in freezing experiments is reviewed, and the water behavior in the micro 
porous layers and GDL is discussed. The paper was originally written for the keynote speech in the ICNMM conference of ASME in 2011, and the major part of the paper consists of the research presented at the conference of the Electrochemical Society in 2009 [1] and some in the Journal of Power Sources in 2011 [2], together with newly obtained results so far unpublished.

As the first report by the author on freezing phenomena in fuel cells, images obtained with infrared thermography were presented detailing the freezing behavior in PEMFCs. The thermographs showed the 2-dimentional propagation in the higher temperature region to be caused by the released solidification heat [3]. Ishikawa et al. reported a detailed, real-time observation of a fuel cell cross-section using infrared images at $-10^{\circ} \mathrm{C}$ cold starting [4]. The results there indicate that the ice formation at the interface between the gas diffusion layer (GDL) and the membrane electrode assembly (MEA) limits the diffusion of air to the reaction zone, resulting in the decreases in performance. The surface of the catalyst layer (CL) was also observed by visible light and infrared images at $-10^{\circ} \mathrm{C}$ cold starting, showing water to be in a super-cooled state at the catalyst surface at $-10^{\circ} \mathrm{C}$ [5]. Ge et al. investigated the ice formation in the catalyst layer by cyclic voltammetry [6]. Tajiri et al. estimated the ice distribution in the catalyst layer using a well controlled gas-purge process and differential current densities 
[7, 8]. To understand further details of the ice formation in the catalyst layer, CRYO-SEM observations have been conducted [9, 10]. Additionally, numerical research has been presented as a useful method to clarify the freezing mechanism in simulations [11].

Despite the research detailed above, the understanding of these freezing phenomena is not sufficient to be able to design a PEMFC structure which is optimally tolerant to cold starting and employing a minimum of heating for the cells.

For water transport phenomena at regular temperatures, Wang has provided an overview on the research of two-phase visualization, current distribution, high-frequency resistance measurements, and the research on mass and temperature distributions in fuel cells [12]. The water production behavior in the cathode separator channel has been investigated using transparent fuel cells, and the relationship between liquid water behavior and the cell performance was demonstrated [13, 14]. Liquid water removal from gas channels has also been characterized in detail [15]. The effects of the distribution of the generated water and the gas composition on cell performance were discussed using measured results of the current density distribution [16, 17]. For the relationships among the local phenomena, the distribution of purely ohmic cell resistance, the diffusivity in the electrodes and the free gas volume of cells have been 
measured using the galvanostatic discharge of a fuel cell [18]. The simultaneous measurements of species concentrations and current density distributions were conducted using a segmented cell [19], and there is a report of the experimental approach to measure the spatially resolved water crossover coefficient [20]. The author and coworkers have observed phenomena related to water production behavior inside a cell and analyzed the effects on the current and the temperature distributions across the reaction area $[21,22]$. Other relationships between the local humidity and current distribution [23], and the relationships between the local cell impedance and current density [24] have also been reported.

As described above, a very large volume of research has been conducted, however, there is still a need for wide ranging research with different experiments to elucidate further details of the effects and mechanisms of local transport phenomena on the performance of Polymer electrolyte membrane fuel cells (PEMFCs).

\section{BASIC STRUCTURE OF FUEL CELLS AND MICRO CHANNEL LAYERS}

This section explains the basic structure of fuel cells and micro channel layers in a fuel cell. Figure 1 is a general outline of the basic structure of a fuel cell with a membrane electrode assembly (MEA) in the center. The MEA consists of two catalyst 
layers (CL) with ca. $20 \mu \mathrm{m}$ thicknesses at both sides of a polymer electrolyte membrane with a thickness of ca. $80 \mu \mathrm{m}$. The MEA is sandwiched by gas diffusion layers (GDL), about $300 \mu \mathrm{m}$ thick, and these layers are further sandwiched by bipolar plates, also termed separators. The GDL usually has a ca. $70 \mu \mathrm{m}$ micro porous layer (MPL) in one side in contact with the catalyst layer. As suggested by the micrographs in Fig. 2, the GDL consists of a coarse random mesh of carbon fibers with pore diameters of around 10-30 $\mu \mathrm{m}$ and a porosity of ca. $75 \%$, whereas the MPL is a fine layer with pores of around $0.1-0.5 \mu \mathrm{m}$. The MPL has the roles of protecting the catalyst layers from the rough and irregular GDL fibers, providing better contact resistance at the interface, and better water management characteristics for dealing with flooding and dry-out events, which deteriorate the proton conductivity in the membrane as the water content in the membrane then is very low. However the mechanisms required for optimum water management characteristics by the MPL are not well understood, yet. As shown in Fig. 2 water is produced in the catalyst layer in the cathode, and transfers to the separator channels through the various layers. Here there is no general agreement on what the phase of the water transferring through the MPL is, i.e. whether it is liquid or vapor. It is also unclear how liquid water distributes in the layers and what kind of structures of the layers would be optimal for the water management. 


\section{EXPERIMENTAL APPARATUS AND METHOD}

\section{Experimental setups}

The experiments were divided into two kinds. One is cold starting in a thermostatic chamber and the other is observation in the chamber and in a CRYO-SEM unit. Figure 3 shows a schematic outline of the fuel cell test unit used in the cold start experiments and in the microscopic observations of the MEA surface. The experimental apparatus and a picture of the working arrangements inside the thermostatic chamber are shown in Fig. 4. A single cell with an active area of $25 \mathrm{~cm}^{2}$ was used for the cold start experiments. Separators on the anode and cathode sides were made of carbon with straight channels, and the width of the channels and ribs, which are sometimes called lands, were $1.0 \mathrm{~mm}$, with the channel height $0.5 \mathrm{~mm}$. In the experiments, the cell was set vertically, and the cell temperature was controlled by the chamber temperature and silicon rubber heaters placed on the cathode and anode sides. The experiments were conducted with pure hydrogen as the anode gas, and synthetic air (oxygen $21 \%$, nitrogen $79 \%$ ) as the cathode gas. The cell resistance was measured by an alternating impedance meter at $1 \mathrm{kHz}$. The cell voltage, impedance, pressure drop, and current densities were recorded on a computer at one second intervals. The 
procedures and steps of this experiment are shown in Fig. 5.

\section{Cold start experiment and microscopic observations}

The procedure of the cold start experiments consists of four steps:

preconditioning, gas purge, cooling down, and the cold start. In the gas purging process, the initial water conditions in the cell were carefully controlled, because residual water in the cell strongly affects the cold start characteristics [8]. The dry $\mathrm{N}_{2}$ gas purge was conducted to eliminate the water in the cell and was continued until the measured cell resistance increased to a specific value, then the wet $\mathrm{N}_{2}$ gas purge was conducted to achieve an equilibrium state of the MEA until the resistance was kept steady. These procedures lasted about 5hours. After this the cell and chamber temperature were cooled down to the target temperature of $-10^{\circ} \mathrm{C}$ or $-20^{\circ} \mathrm{C}$, the cell operation was started at a constant current density until the cell shut down due to freezing.

To prepare for the observations, the following procedures were conducted. After the termination of the cold start experiment, the cell was disassembled into its component parts in the thermostatic chamber kept below freezing to remove the MEA from the cell. Then the surface of the MEA was observed by the microscope installed in the thermostatic chamber at the same temperature, still below freezing. Here, the focus and the observation position were adjusted using a motor-driven $\mathrm{XYZ}$ stage in the 
chamber with LED lightning used as the light source, to avoid melting of the ice crystals.

For the CRYO-SEM observations, the MEA was removed from the cell and rapidly immersed in liquefied nitrogen in the chamber. The MEA was cut into pieces of approximately $5 \times 5 \mathrm{~mm}$ size and these were set on sample holders in the liquefied nitrogen. Then, the sample was moved to the preparation chamber at $-160^{\circ} \mathrm{C}$ in the CRYO-SEM, and the air in the chamber was evacuated. The sample was cut by a cold knife in the chamber, and the cut section surfaces were coated by platinum vapor. Finally the samples were observed by a CRYO-SEM at $-164^{\circ} \mathrm{C}$ with an acceleration voltage of $5 \mathrm{kV}$.

\section{RESULTS AND DISCUSSION}

\section{Characteristics of cold start}

The cold start characteristics at below freezing temperatures, for $0.04 \mathrm{~A} / \mathrm{cm}^{2}$ at $-10^{\circ} \mathrm{C}$ and $-20^{\circ} \mathrm{C}$, were investigated with a single cell fuel cell. $\mathrm{N}_{2}$ gas with relative humidity (RH) $21 \%$ was used in the previously mentioned wet-purge process at $60^{\circ} \mathrm{C}$. Figure 6 shows the behavior of cell voltage and resistance at the cold start operation [25]. The cell resistance decreases at first because the generated water humidifies the 
membrane due to back diffusion. At $-20^{\circ} \mathrm{C}$, the back diffusion terminates at around 300 seconds, and then the cell voltage starts falling rapidly, and at the same time the cell resistance increases slightly. At $-10^{\circ} \mathrm{C}$, the cell voltage gradually decreases after around 500 seconds and operation shuts down at around 700 seconds. These voltage drops are caused by the freezing of the water produced in the cell. The results in Fig. 6 show that the freezing characteristics in the cell are different at the two start-up temperatures.

\section{Optical and CRYO-SEM observation}

After the shutdown, the cell was disassembled, and the MEA surface of the cathode side was observed as detailed above. Figure 7 shows micrographs of the cathode catalyst surface at the two temperatures. At $-10^{\circ} \mathrm{C}$, there are numerous ice layers throughout the MEA surface, while few ice crystals were observed at $-20^{\circ} \mathrm{C}$. These results indicate that at $-10^{\circ} \mathrm{C}$ the produced water transfers through the catalyst layer (CL) and freezes at the CL/MPL interface. At $-20^{\circ} \mathrm{C}$ most of the produced water appears to freeze in the CL.

The volume of produced water was calculated from the operation period and the current density, and the amount of water removed by the dry gas as vapor was also considered. It was confirmed that the accumulated water amount was the same for the cases with a current density of $0.08 \mathrm{~A} / \mathrm{cm}^{2}$ at $-10^{\circ} \mathrm{C}$ and $0.02 \mathrm{~A} / \mathrm{cm}^{2}$ at $-20^{\circ} \mathrm{C}$. The 
observed cathode side surfaces appeared similar to those mentioned above, shown in Fig. 7. Therefore, it may be concluded that the differences in the ice formation are caused not by the water amount produced but by the differences in the start-up temperatures. To investigate more details of the ice formation in the catalyst layer, cross sections of the cathode catalyst layer were observed by CRYO-SEM.

For the CRYO-SEM tests the cell before operation and after the cell shutdown at $-20^{\circ} \mathrm{C}$ was used, and the cross section of the cathode catalyst layer was observed by CRYO-SEM. Figure 8 shows micrographs of the dry pre-operation MEA catalyst layer (a), and the MEA catalyst layer after the cold start operation (b). Compared with the dry catalyst layer (Fig. 8 (a)), ice formation is clearly observed in the cathode catalyst layer at the region enclosed by the oval (Fig. 8 (b)). This ice is considered to obstruct the supply of oxygen to the catalyst surface and cause the shutdown. More ice was observed in the catalyst layer after the cold start at lower current densities, when the accumulated water volume was larger due to longer operation before the shutdown. This may be explained by the operation at the lower current density tolerating a larger amount of ice formation due to the smaller free area necessary for the reaction to proceed.

Figure 9 shows cross sections of the cathode layers at the end of the back 
diffusion period at $270 \mathrm{sec}$. (a); and after the complete shutdown at $370 \mathrm{sec}$. (b), when using pure oxygen as the cathode gas at $0.04 \mathrm{~A} / \mathrm{cm}^{2}$. In Fig. 9 (a), a large amount of ice is observed at the PEM side in the catalyst layer. This is different from the case with air shown in Fig. 8 (b), where the ice is formed from the MPL side. The difference is due to the factors controlling the reaction in the catalyst: oxygen diffusion control with air and proton diffusion control with oxygen. Figure 9 (b) shows the ice covered catalyst layers, and compared to the air case in Fig. 8 (b) it shows that the cell can be operated with a smaller reaction area with oxygen than with air.

\section{Performance deterioration at normal operating temperatures after cold starting}

After the shutdown at the cold start operation, the cell was heated to $30{ }^{\circ} \mathrm{C}$ and the performance was compared to the values before the cold start. Figure 10 shows the results after the cold start at $-10^{\circ} \mathrm{C}$. As clearly seen in the figure, cell performance has not recovered to the original values, and the deterioration is more significant at lower current density conditions at the cold start, which corresponds to larger amount of accumulated ice in the cell.

Figure 11 is a photo of ice formed on the surface of the MEA after cold starting. A large amount of ice is formed on the surface of the MEA, particularly at the region under the channels rather than under the ribs, which are subject to a higher contact 
pressure than the channels. The deteriorated performance continues for over $1500 \mathrm{sec}$. at about $30{ }^{\circ} \mathrm{C}$ in Fig. 10, after which the performance has recovered to the original level at the $80^{\circ} \mathrm{C}$ cell temperature (data not shown). After the cold start at $-20^{\circ} \mathrm{C}$, there was no deterioration in the performance and the cell voltage was at the same level before and after the cold start.

These results indicate that the water melted from the ice at the interface between the MEA and MPL limits the gas diffusion in the operation at $30{ }^{\circ} \mathrm{C}$, and that the ice formed in the catalyst layer at the cold start does not affect the gas diffusion after the temperature recovery at $30{ }^{\circ} \mathrm{C}$. These phenomena appear to be related to the function of the MPL, which will be discussed in the next section.

\section{Function of MPL for water transport}

Figure 12 plots the cell performance with and without MPL; some of the related results were presented in the ECS conference in 2011 [26]. Many experimental data have shown that fuel cells with an MPL offer better cell performance than cells without an MPL. To observe the water amount at the interface between the MEA and GDL, a cell was operated for a sufficiently long time to reach the equilibrium state, then stopped and frozen to $-30^{\circ} \mathrm{C}$. Following the freezing the cell was disassembled and the surface of the MEA was observed to establish the amount of ice formed at the 
interface. Figure 13 shows photos of the ice at the interface of the cells with (left) and without MPL (right). To identify the ice locations, image processing was performed to subtract the images with ice from the images without ice after evaporation of the ice (achieved by raising the temperature). The ice is shown as white in the figures and they clearly show that more ice is formed at the interface without the MPL than with the MPL. This suggests that cells with an MPL has less water accumulating at the interface and so that there is more water transported to the GDL from the interface.

With the cold start at $-10^{\circ} \mathrm{C}$ shown in the previous section, this difference in water transport volumes may be interpreted as the accumulated ice creating a larger space in the interface. This larger space allowed liquid water to remain at the interface even after heating to $30{ }^{\circ} \mathrm{C}$, and the presence of this water was a cause of the deterioration in the cell performance shown in the previous section. When the cell was heated to above $80^{\circ} \mathrm{C}$, the volume of this space decreased and became equal to that before freezing, and the cell performance recovered to the previous level. This interpretation suggests the role of the MPL as a factor limiting the water amount at the interface, caused by the close contact between the two layers. The mechanism is possible even with liquid water, which requires a high capillary pressure to be transported through the narrow pores of the MPL. This situation arises when the space 
is sufficiently small, and here the water involved need not be in the vapor phase.

\section{Freezing method to identify the water distribution in the GDL}

There is much research on the cross sectional water distribution in the GDL

using neutron CT and X-ray CT. However these technologies require special cell structures and the spatial resolution is not adequate for a full elucidation of the conditions at the GDL. To get around this, a method was developed to freeze the cell after operation and to observe cross sections of the GDL [2]. For this experiment a cell like that shown in Figure 14 was specially made. It has bipolar plates consisting of two separate sections for each side of the cathode and anode, and the two sections are connected to each other by filling the space between them with a silicon sheet. This cell allows observation of the water distribution in the form of ice inside the GDL. After the cell has operated for a sufficient time, operation is stopped, and the cell is frozen to $-30^{\circ} \mathrm{C}$ over a period of about 30 minutes in a thermostatic chamber. In the frozen state, the cell was disassembled into its component parts, still in the thermostatic chamber. Then the GDL is cut into two pieces with a sharp knife at the silicon interface, while still in the thermostatic chamber, to observe the cross sectional ice distribution. The observations were performed by a microscope in the thermostatic chamber. The cutting paid attention to the need to obtain good images of the frozen water because the 
sectioning itself may cause delamination. Image processing was performed to identify the ice locations by comparing pictures taken with the frozen water deposits and pictures taken after the ice had evaporated.

To confirm that the water within a fuel cell does not redistribute itself and move from region to region during the frozen period, the water behavior in the channels were observed during the frozen period through a glass window. The photos showed that the ice location within the cell at the freezing state was similar to the liquid water distribution at the time when operation was stopped. As the water moves through the pore networks in the GDL, the liquid water appears to stay in the pores during the whole period, showing the state of water distribution at the time before freezing.

Figure 15 shows examples of such photographs, where the areas of the ice in the GDL are indicated, and the percentage of the areas with ice are shown for the regions under the channels and under the ribs. Figure 16 is a graph showing the average values of the ice area after several experiments at the same conditions. It compares the results with different fiber directions of anisotropic GDLs at the current density at $1 \mathrm{~A} / \mathrm{cm}^{2}$ [2]. The results indicate that the GDL with an anisotropic fiber direction parallel to the channel holds more water than a GDL with the fibers in the perpendicular direction (normal to the channel direction), and that the water amount is larger under the 
ribs than under the channels.

The above results demonstrate the potential of the freezing method for investigation of the water distribution in GDLs.

\section{SUMARY}

In Polymer electrolyte membrane fuel cells, it is important to understand the water transport phenomena to be able to realize better cell performance. The paper for the keynote speech presents details of the ice formation characteristics in the catalyst layer and in the gas diffusion layer (GDL) during cold starting. It also shows the differences in the water distribution at the interface between the catalyst layer and the GDL that arise from the presence of the micro porous layer. Additionally an example of the freezing method applied to the investigation of the water distribution in the GDL is demonstrated. The aim of the author of the paper is to give an idea of the water behavior inside fuel cells and how this is related to two phase flow in the micro channels.

\section{ACKNOWLEDGMENTS}

This research was supported by Nissan Motor Co. Ltd. and the Scientific 
Research Program of the Ministry of Education, Culture, Sports, Science and Technology, Japan. Appreciation is expressed to Prof. Tabe, an associate professor in the author's laboratory, for his important contributions in the research as a colleague of the author. Appreciation is also extended to graduate students, M. Saito, K.S.S. Naing, R. Ichikawa, M. Kadowaki, and K. Endo, for their part in the research.

\section{REFERENCES}

[1] M. Saito, Y. Tabe and T. Chikahisa, Microscopic Observation of Freezing Phenomena in PEM Fuel Cell at Cold Start, Electrochemical Society Transactions, vo. 25 , no. 1, pp. 773-779, 2009.

[2] Kyaw Swar Soe Naing, Y. Tabe, and T. Chikahisa, Performance and liquid water distribution in PEFCs with different anisotropic fiber directions of the GDL, Journal of Power Sources, vol. 196, pp. 2584-2594, 2011.

[3] Y. Tabe, H. Nakamiya, K. Kikuta, T. Chikahisa, F. Kagami, K. Yoshizawa, Study on freezing phenomena in PEM fuel cell blow freezing, Proceedings of the 13th International Heat Transfer Conference, Sydney, Australia, (CD-ROM) SOL-08, pp. $1-8,2006$

[4] Y. Ishikawa, H. Hamada, M. Uehara, M. Shiozawa, Super-cooled water behavior 
inside polymer electrolyte fuel cell cross-section below freezing temperature, Journal of Power Sources, vol. 179, pp. 547-552, 2008

[5] Y. Ishikawa, T. Morita, K. Nakata, K. Yoshida, M. Shiozawa, Behavior of water below the freezing point in PEFCs, Journal of Power Sources, vol. 163, pp. 708-712, 2007

[6] S. Ge, C. Y. Wang, Cyclic Voltammetry Study of Ice Formation in the PEFC Catalyst Layer during Cold Start, Journal of Electrochemical Society, vol. 154, no. 12, pp. B1399-1406, 2007

[7] K. Tajiri, Y. Tabuchi, C-Y. Wang, Isothermal Cold Start of Polymer Electrolyte Fuel Cells, Journal of Electrochemical Society, vol. 154, no. 2, pp. B147-152, 2007

[8] K. Tajiri, C-Y Wang, Y. Tabuchi, Water removal from a PEFC during gas purge, Electrochimica Acta, vol. 53, pp. 6337-6343, 2008

[9] E. L. Thompson, J. Jorne, W. Gu, H. Gasteiger, PEM Fuel Cell Operation at $-20^{\circ}$ C. I. Electrode and Membrane Water (Charge) Storage, Jornal of Electrochemical Society, vo. 155, no. 6, pp. B625-634, 2008

[10] J. Li, S. Lee, J. Roberts, Ice formation and distribution in the catalyst layer during freeze-start process - CRYO-SEM investigation, Electrochimica Acta, vo. 53, pp. 
5391-5396, 2008

[11] F. Jiang, W. Fang, C-Y. Wang, Non-isothermal cold start of polymer electrolyte fuel cells, Electrochimica Acta, vol. 53, pp. 610-621, 2007

[12] C. Y. Wang, Fundamental models for fuel cell engineering, Invited Review Article for Chemical Reviews, vol. 104, pp. 4727-4766, 2004

[13] K. Tüber, D. Pócza, C. Hebling, Visualization of water buildup in the cathode of a transparent PEM fuel cell, Journal of Power Sources, vol. 124, pp. 403-414, 2003

[14] X. G. Yang, F. Y. Zhang, A. L. Lubawy, C. Y. Wang, Visualization of Liquid Water Transport in a PEFC, Electrochemical Solid-State Letters, vol. 7, no. 11, pp. A408-A411, 2004

[15] F. Y. Zhang, X. G. Yang, C. Y. Wang, Liquid Water Removal from a Polymer Electrolyte Fuel Cell, Journal of Electrochemical Society, vol. 153, no. 2, pp. A225-A232, 2006

[16] M. Noponen, J. Ihonen, A. Lundblad, G. Lindbergh, Current distribution measurements in a PEFC with net flow geometry, Journal of Applied Electrochemistry, vol. 34, pp. 255-262, 2004

[17] Z. Liu, Z. Mao, B. Wu, L. Wang, V. M. Schmidt, Current density distribution in PEFC, Journal of Power Sources, vol. 141, pp. 205-210, 2005 
[18] J. Stumper, M. Löhr, S. Hamada, Diagnostic tools for liquid water in PEM fuel cells, Journal of Power Sources, vol. 143, pp. 150-157, 2005

[19] X. G. Yang, N. Burke, C. Y. Wang, K. Tajiri, K. Shinohara, Simultaneous Measurements of Species and Current Distributions in a PEFC under Low-Humidity Operation, Journal of Electrochemical Society, vo. 152, no. 4, pp. A759-766, 2005

[20] G. Q. Lu, F. Q. Liu, C. Y. Wang, An approach to measuring spatially resolved water crossover coefficient in a polymer electrolyte fuel cell, Journal of Power Sources, vol. 164, pp. 134-140, 2007

[21] T. Chikahisa, Y. Tabe, K. Kikuta, N. Nohara, H. Shinohara, Measurement of Water Production Phenomena, Temperature, and Current Density Distributions in a Polymer Electrolyte Fuel Cell, Proceedings of the 4th International Conference on Fuel Cell Science, Engineering and Technology, CD-ROM 97016, pp. 1-6, 2006

[22] Y. Tabe, K. Kikuta, T. Chikahisa, and M. Kozakai, Basic evaluation of separator type specific phenomena of polymer electrolyte membrane fuel cell by the measurement of water condensation characteristics and current density distribution, Journal of Power Sources, vol. 193, pp. 416-424, 2009

[23] H. Nishikawa, R. Kurihara, S. Sukemori, T. Sugawara, H. Kobayasi, S. Abe, T. 
Aoki, Y. Ogami, A. Marsunaga, Measurements of humidity and current distribution in a PEFC, Journal of Power Sources, vol. 155, pp. 213-218, 2006

[24] W. H.J. Hogarth, J. Steiner, J. B. Benziger, A. Hakenjos, Spatially-resolved current and impedance analysis of a stirred tank reactor and serpentine fuel cell flow-field at low relative humidity, Journal of Power Sources, vol. 164, pp. 464-471, 2007

[25] Y. Tabe, M. Saito, R. Ichikawa, and T. Chikahisa, "Microscopic Observation of Ice Distribution in PEM Fuel Cell”, Proceedings of the ASME/JSME 2011 8th Thermal Engineering Joint Conference, AJTEC2011-44517, pp. 1-6, 2011

[26] K. Kadowaki, Y. Tabe, and T. Chikahisa, "Role of Micro-Porous Layer for Water Transfer Phenomena in PEFC”, ECS Transactions, 41 (1), pp. 431-438, 2011. 


\section{List of Figure Captions}

Figure 1 Basic structure of fuel cells

Figure 2 Schematic cross section of the cathode layers and micrographs of the GDL and MPL layers

Figure 3 Schematic outline of the apparatus developed to evaluate fuel cell performance [1]

Figure 4 Experimental fuel cell arrangement and view of the working arrangements in the thermostatic chamber [1]

Figure 5 Outline of the experimental procedures

Figure 6 Cell voltages and resistance for $0.04 \mathrm{~A} / \mathrm{cm}^{2}$ cold start operation at $-10^{\circ} \mathrm{C}$ and $-20^{\circ} \mathrm{C}[1,25]$

Figure 7 Micrographs of catalyst layer surfaces after shutdown at $-10^{\circ} \mathrm{C}$ and $-20^{\circ} \mathrm{C}[1$, 25]

Figure 8 Micrographs of cross sections of the cathode catalyst layers, (a) before and (b) after the cold start using air at $0.04 \mathrm{~A} / \mathrm{cm}^{2}$ [25]

Figure 9 Micrographs of cross sections of the cathode catalyst layers, (a) during cold start operation and (b) after shutdown, when using pure $\mathrm{O}_{2}$ at $0.04 \mathrm{~A} / \mathrm{cm}^{2}$ [25]

Figure 10 Performance of the cell at $30^{\circ} \mathrm{C}$ after shutdown with the cold start at $-10^{\circ} \mathrm{C}$ for three different current densities, with the values before the cold start

Figure 11 Photos of ice formed on the MEA surface after cold start at $-10^{\circ} \mathrm{C}$; some of the related results are presented in [26]

Figure 12 Plot of cell voltages and resistance with and without an MPL; some of the 
related results are presented in [26]

Figure 13 Effect of MPL on the water amount (white) at the interface between the MEA and MPL; the water is observed in the form of ice after freezing at $-30^{\circ} \mathrm{C}$; some of the related results are presented in [26]

Figure 14 Views of the $2 \mathrm{~cm} 2$ active area PEFC for cross-sectional observations of the GDL and MEA, here the bipolar plates consist of two separate sections [2]

Figure 15 Water in the GDL observed in the form of ice after freezing at $-30^{\circ} \mathrm{C}$ at two locations: under channels and under ribs [2]

Figure 16 Averaged area percentages of water in the GDL observed in the form of ice after freezing at $-30^{\circ} \mathrm{C}$; for anisotropic GDL fiber directions relative to the channel direction and two relative humidity $(\mathrm{RH})$ conditions [2] 


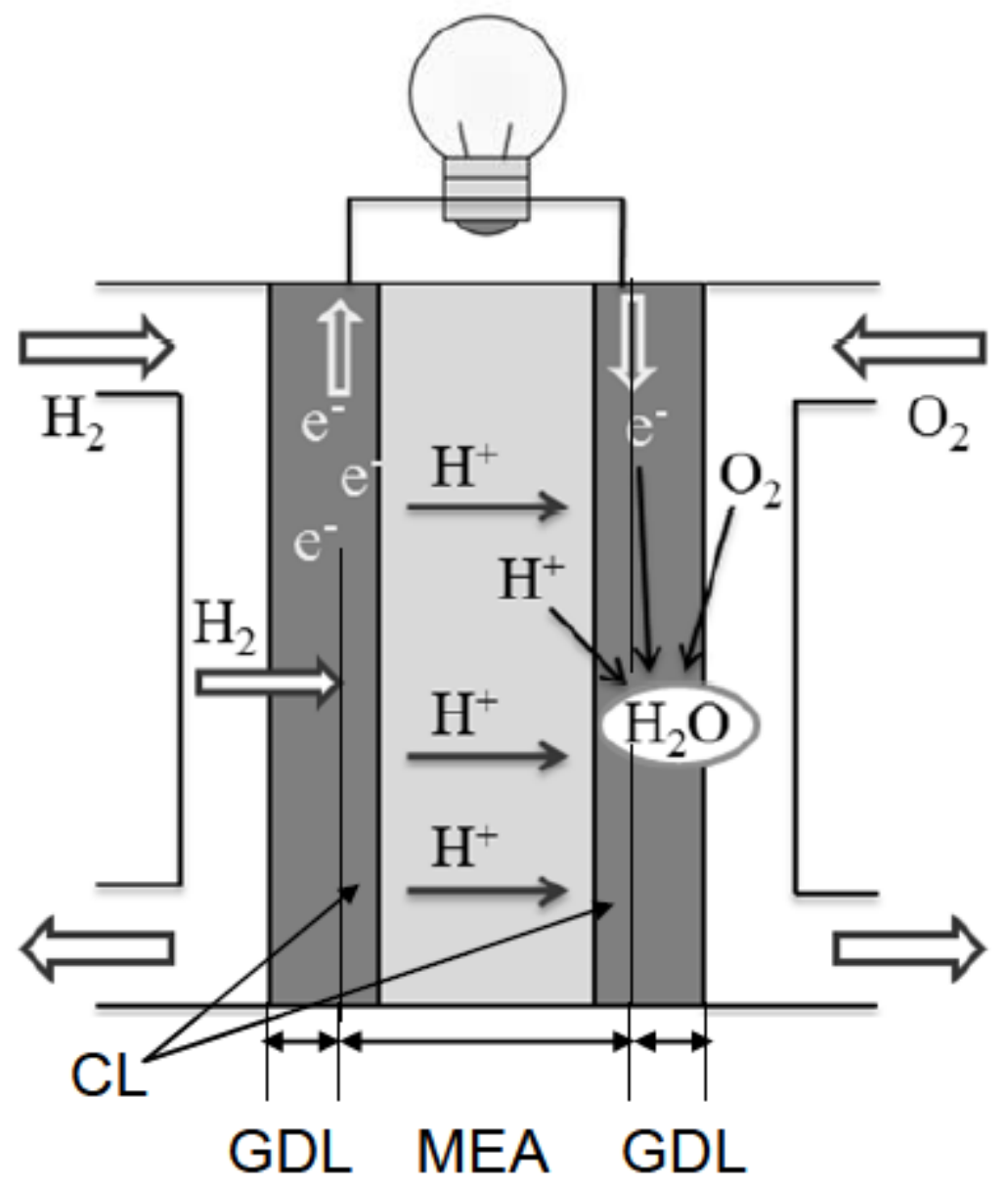

Figure 1 Basic structure of fuel cells 


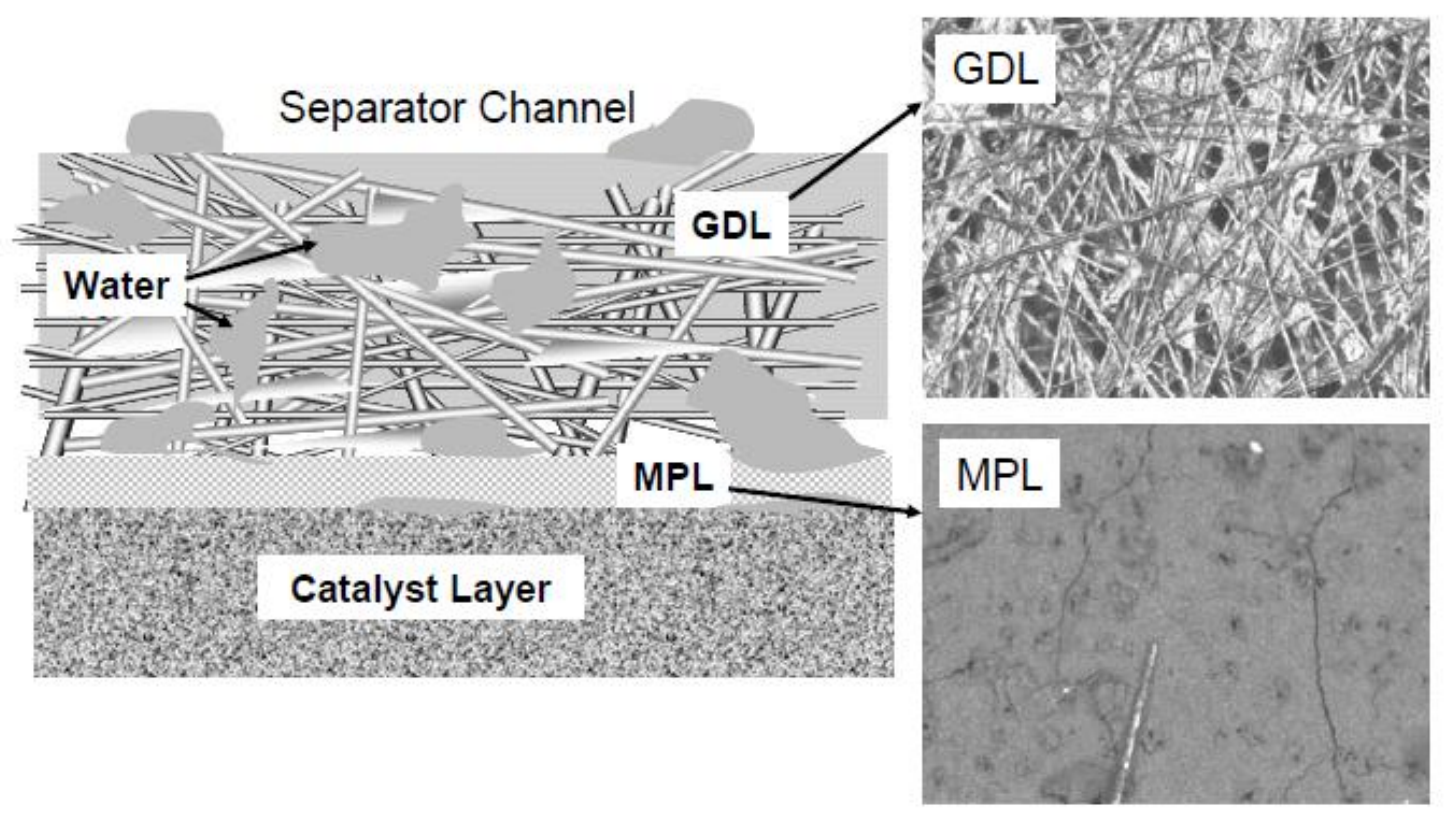

Figure 2 Schematic cross section of the cathode layers and micrographs of the GDL and MPL layers 


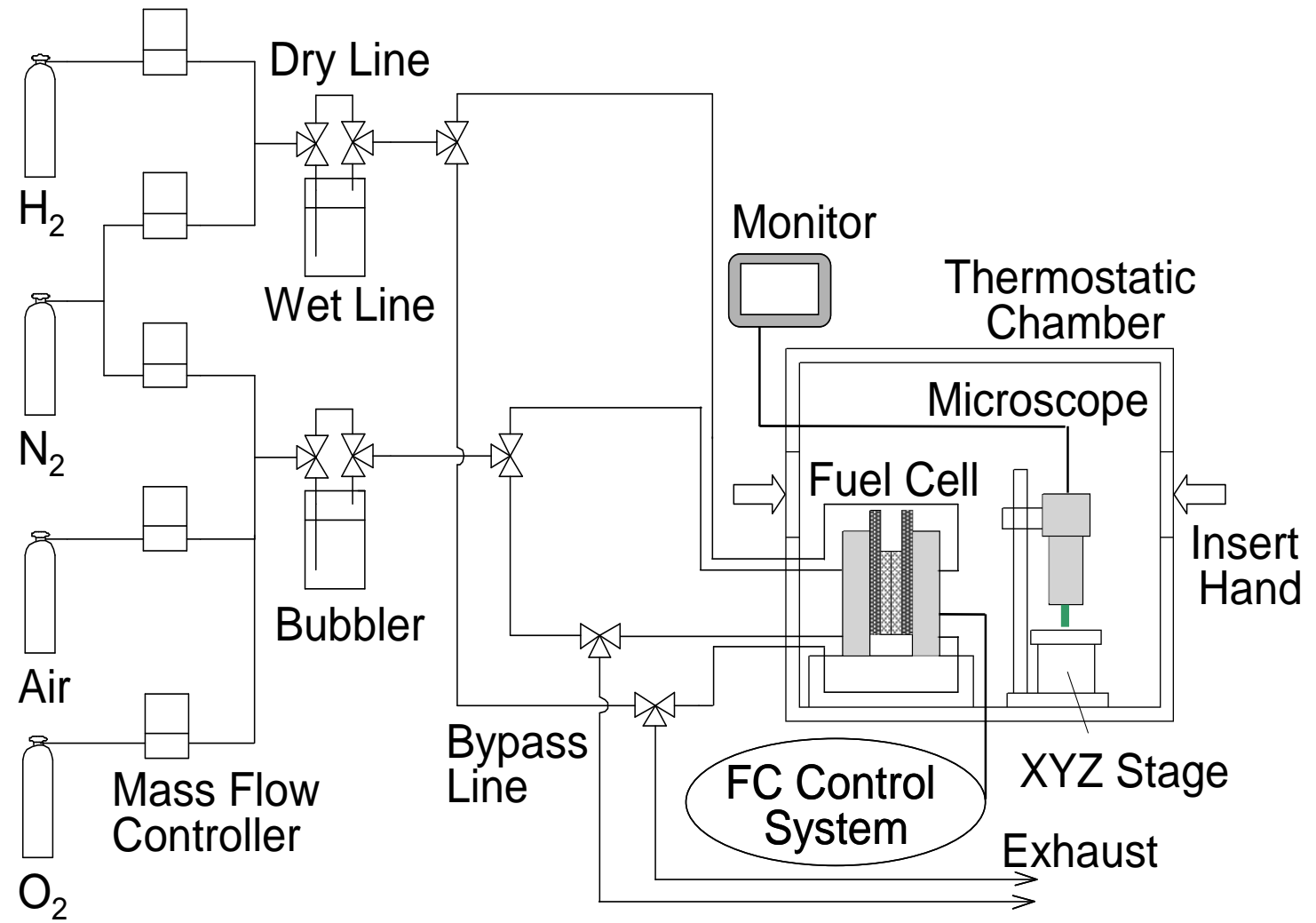

Figure 3 Schematic outline of the apparatus developed to evaluate fuel cell performance [1] 


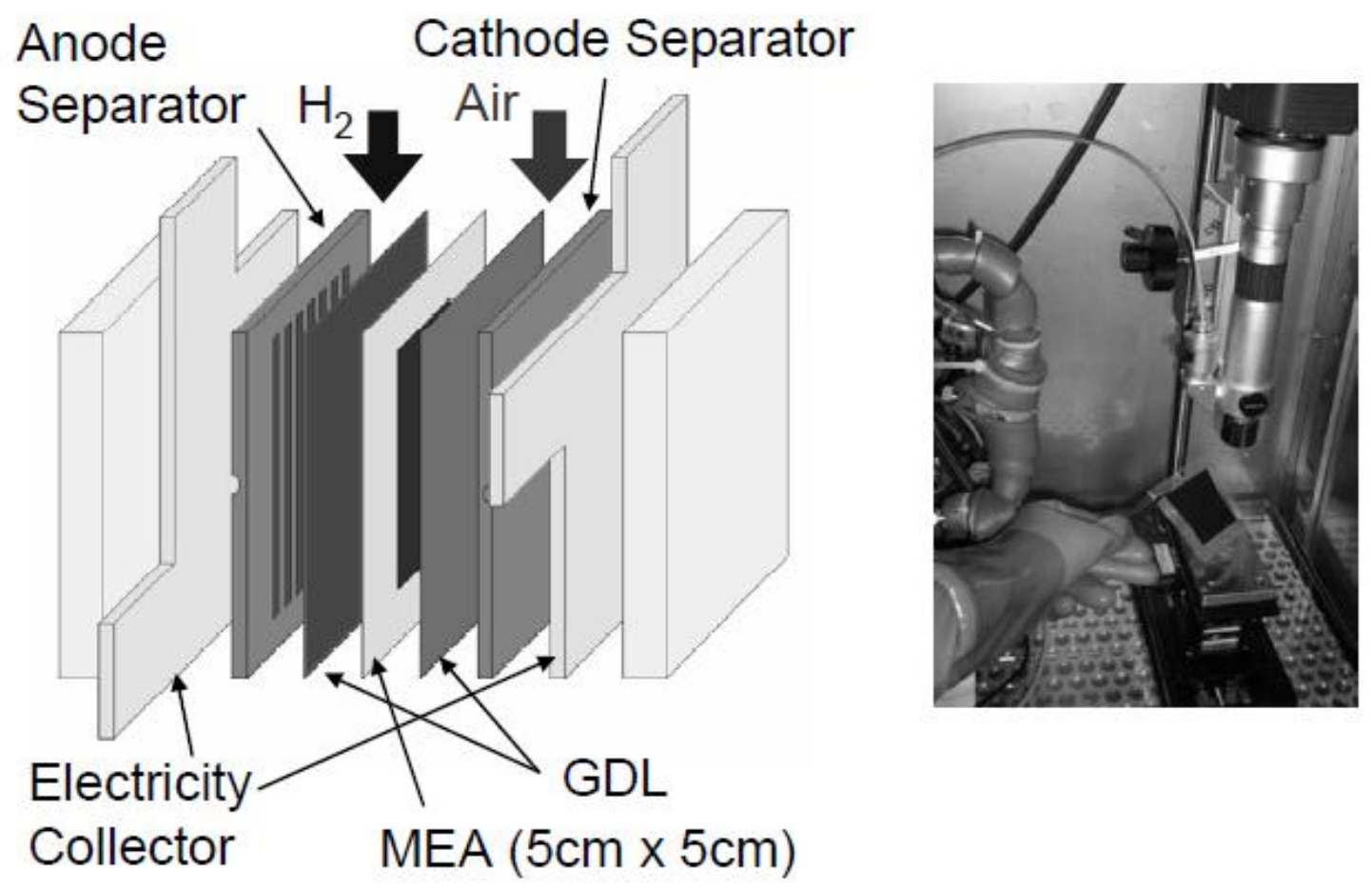

Figure 4 Experimental fuel cell arrangement and view of the working arrangements in the thermostatic chamber [1] 


\section{Thermostatic Chamber}

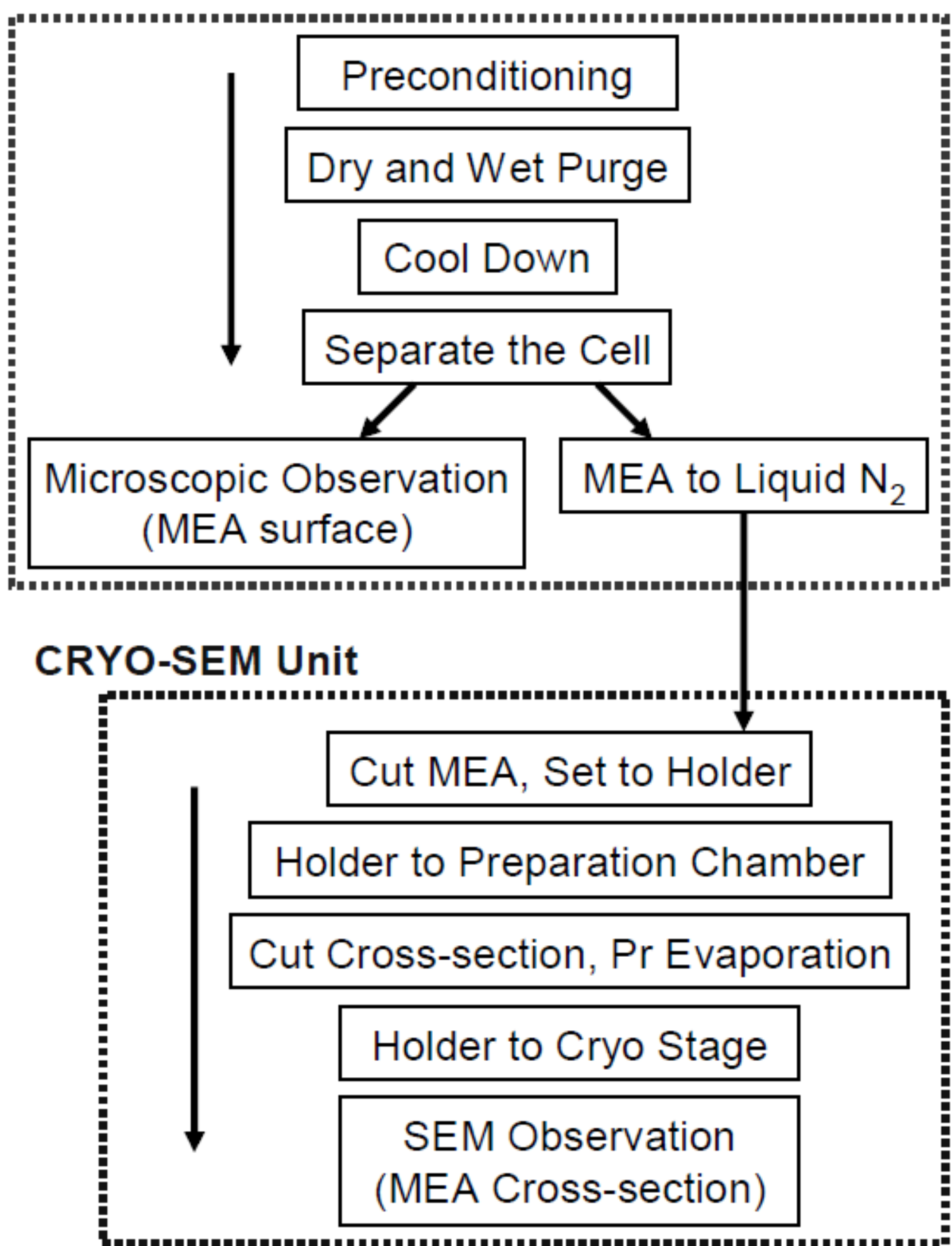

Figure 5 Outline of the experimental procedures 


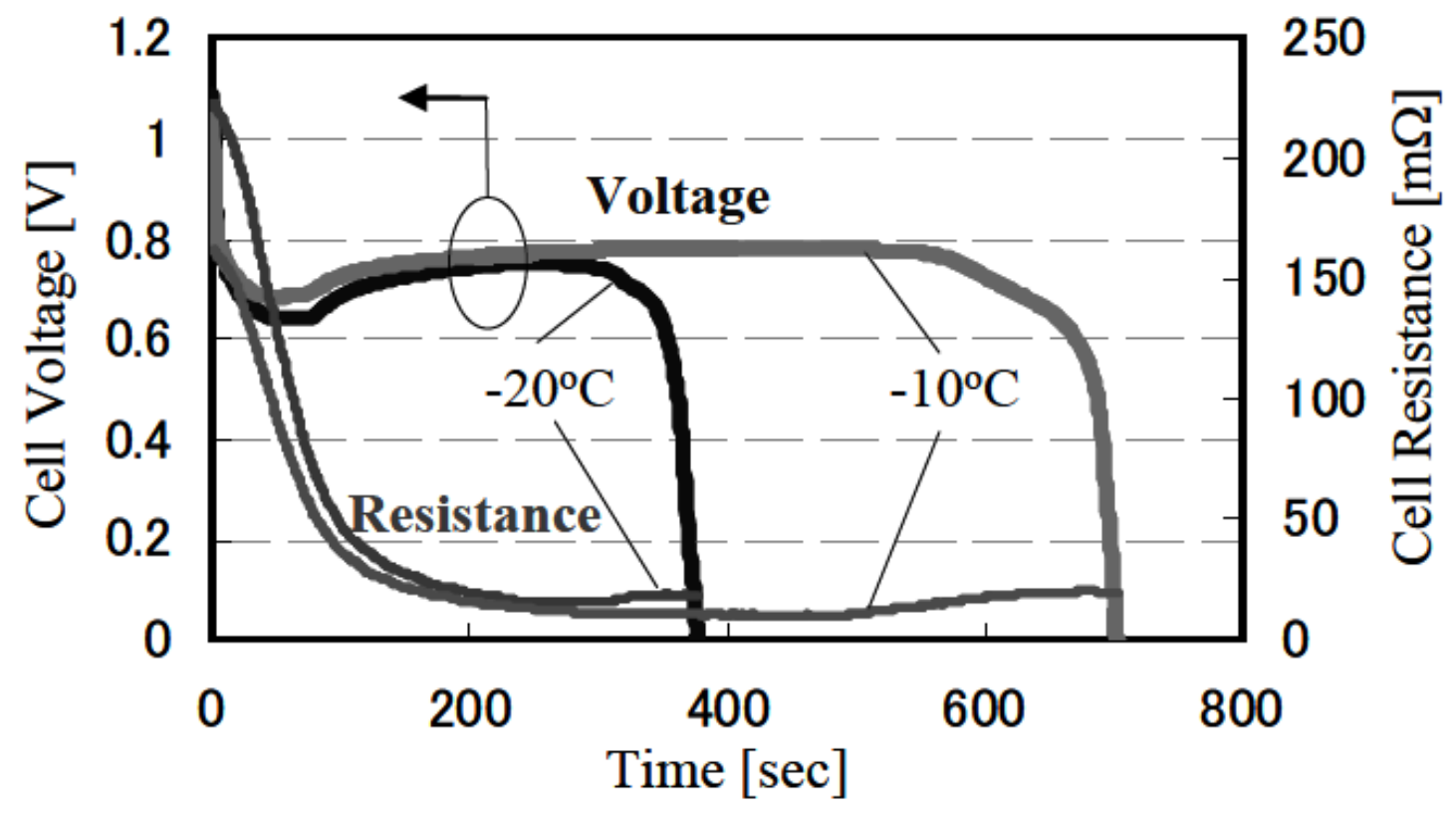

Figure 6 Cell voltages and resistance for $0.04 \mathrm{~A} / \mathrm{cm}^{2}$ cold start operation at $-10^{\circ} \mathrm{C}$ and $-20^{\circ} \mathrm{C}[1,25]$ 


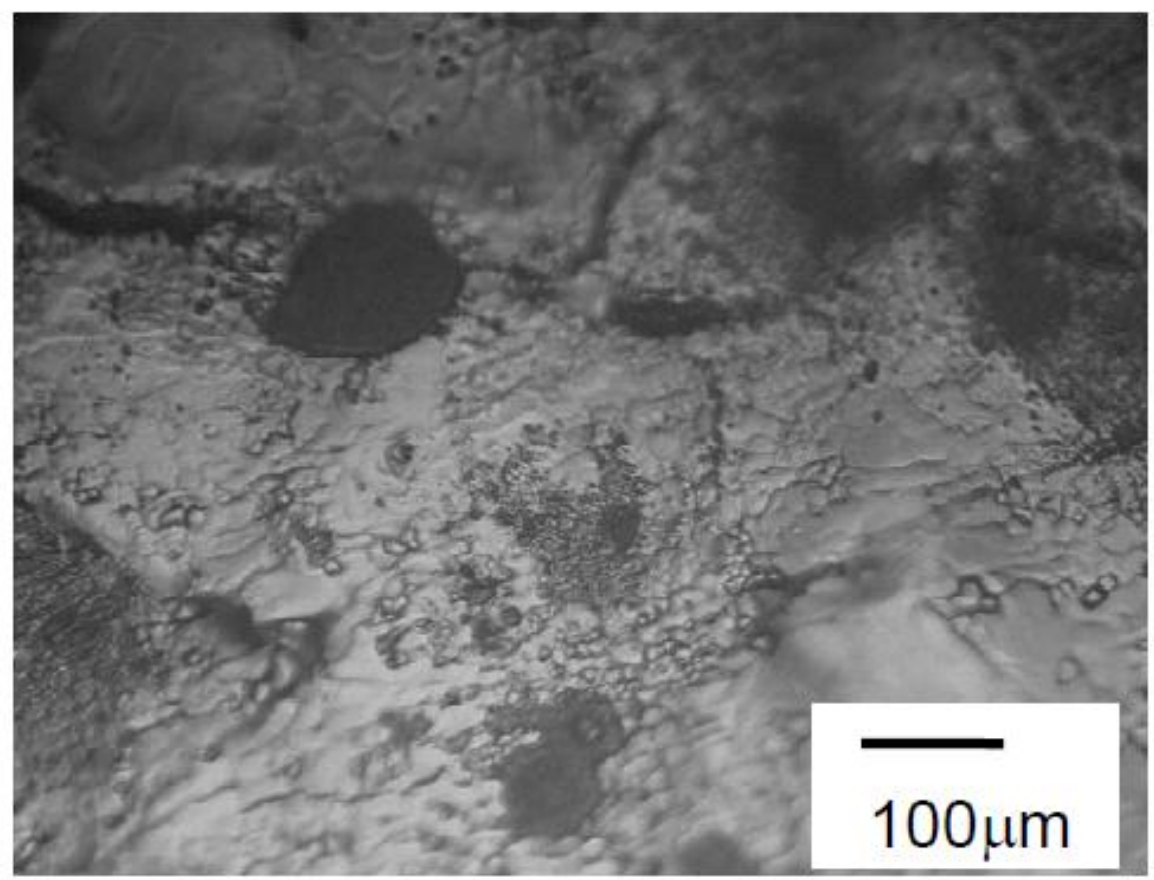

(a) $-10^{\circ} \mathrm{C}$

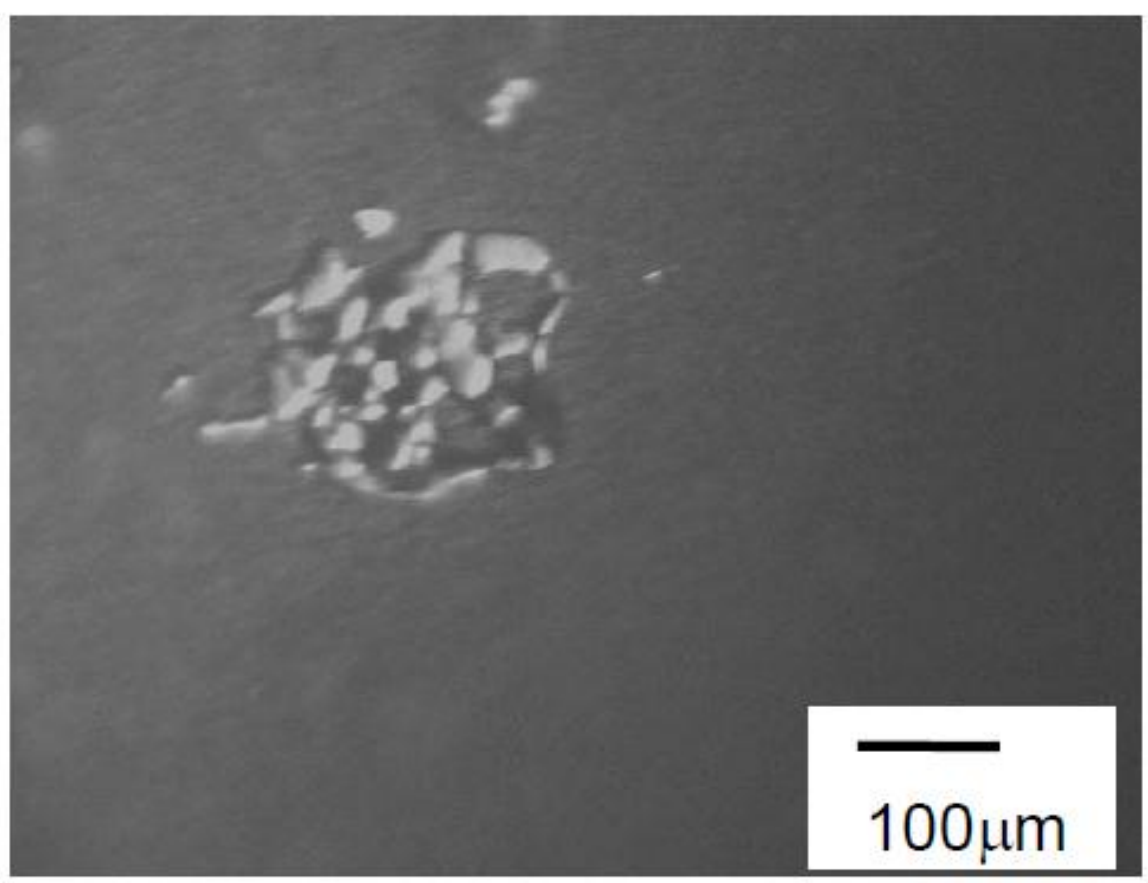

(b) $-20^{\circ} \mathrm{C}$

Figure 7 Micrographs of catalyst layer surfaces after shutdown at $-10^{\circ} \mathrm{C}$ and $-20^{\circ} \mathrm{C}[1,25]$ 


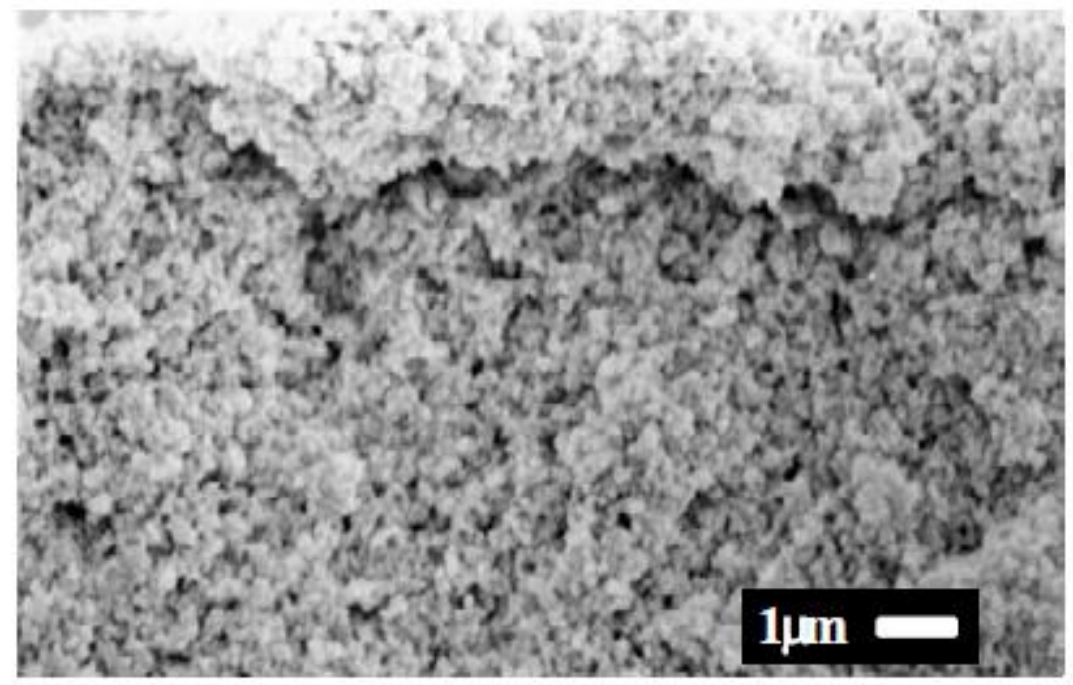

\section{(a) Before operation}

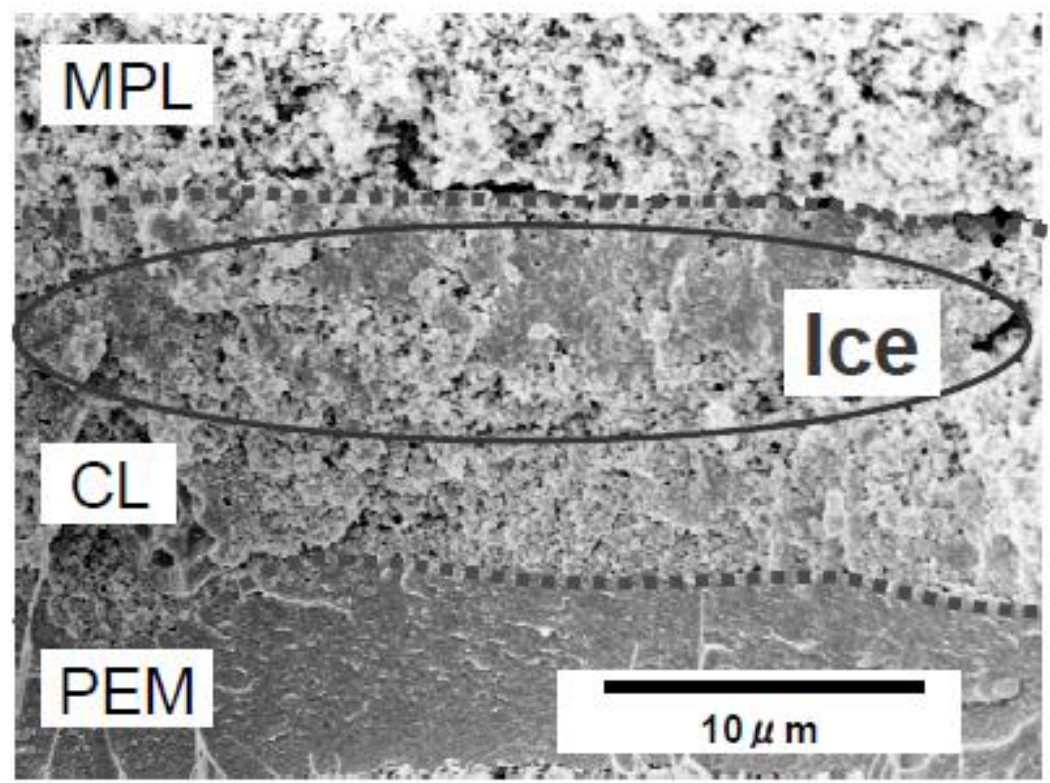

\section{(b) After shutdown}

Figure 8 Micrographs of cross sections of the cathode catalyst layers, (a) before and (b) after the cold start using air at $0.04 \mathrm{~A} / \mathrm{cm} 2$ [25] 


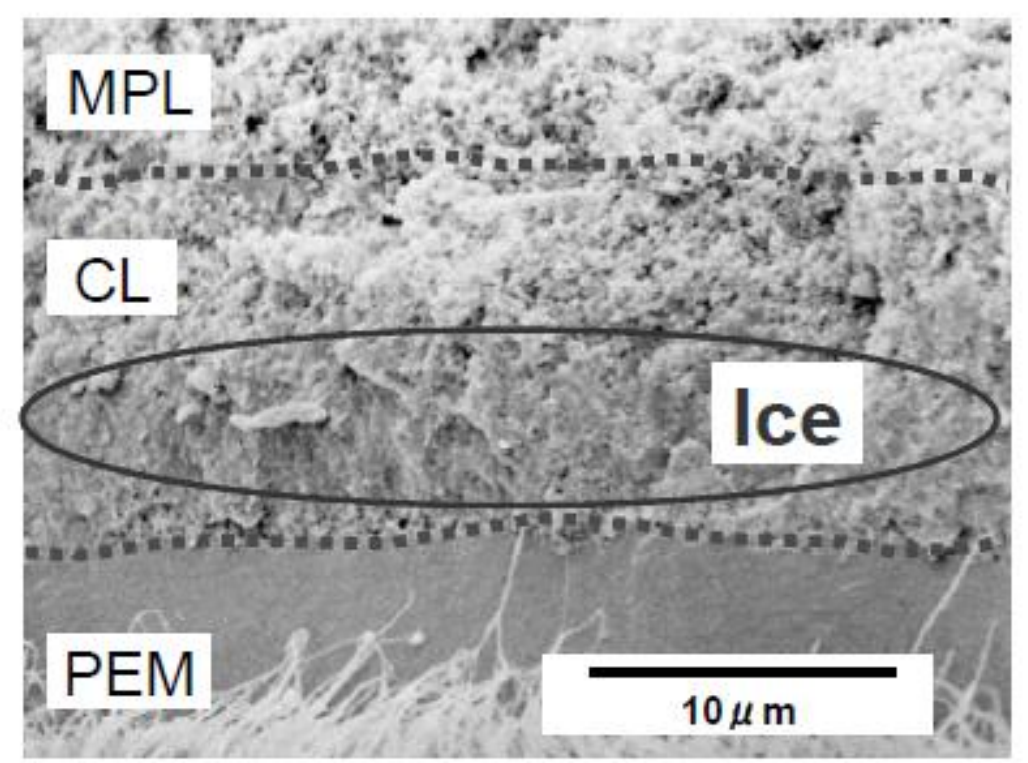

\section{(a) At the end of back diffusion before shut down}

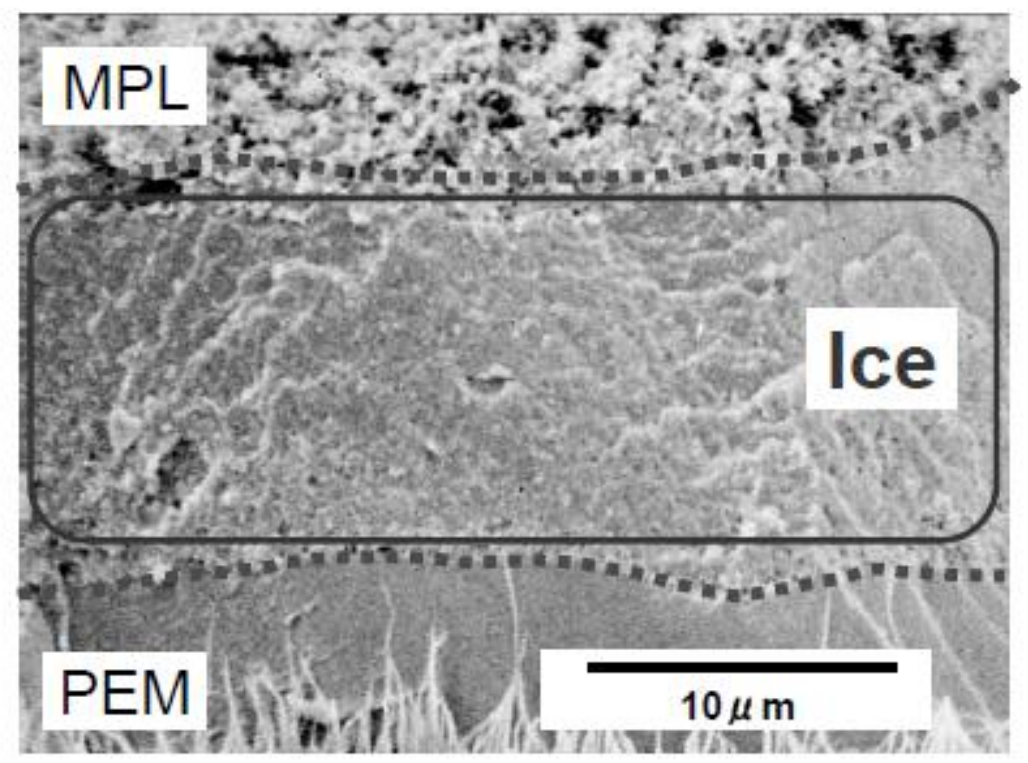

\section{(b) After shutdown}

Figure 9 Micrographs of cross sections of the cathode catalyst layers, (a) during cold start operation and (b) after shutdown, when using pure $\mathrm{O}_{2}$ at $0.04 \mathrm{~A} / \mathrm{cm}^{2}[25]$ 


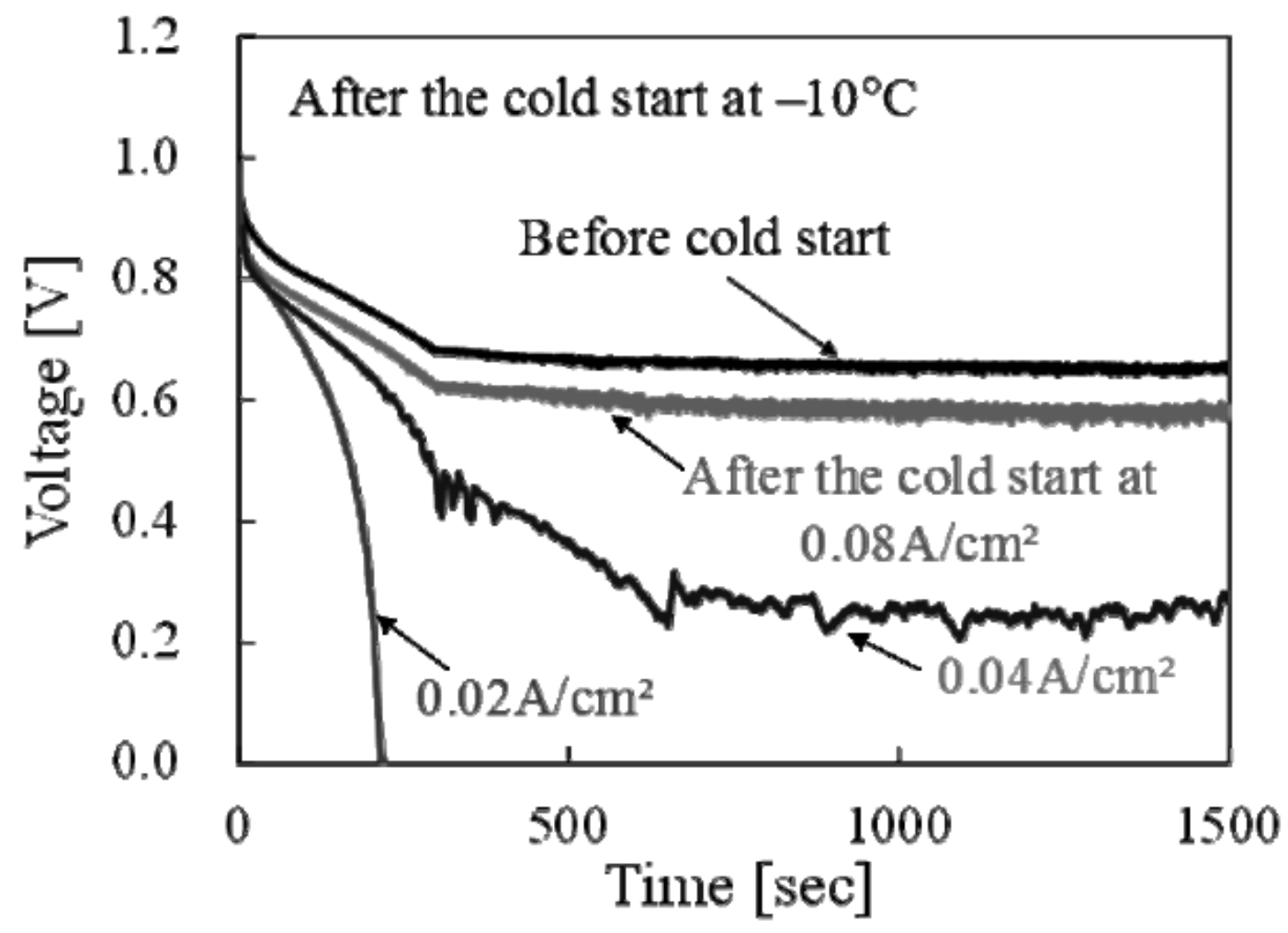

Figure 10 Performance of the cell at $30{ }^{\circ} \mathrm{C}$ after shutdown with the cold start at $-10^{\circ} \mathrm{C}$ for three different current densities, with the values before the cold start 


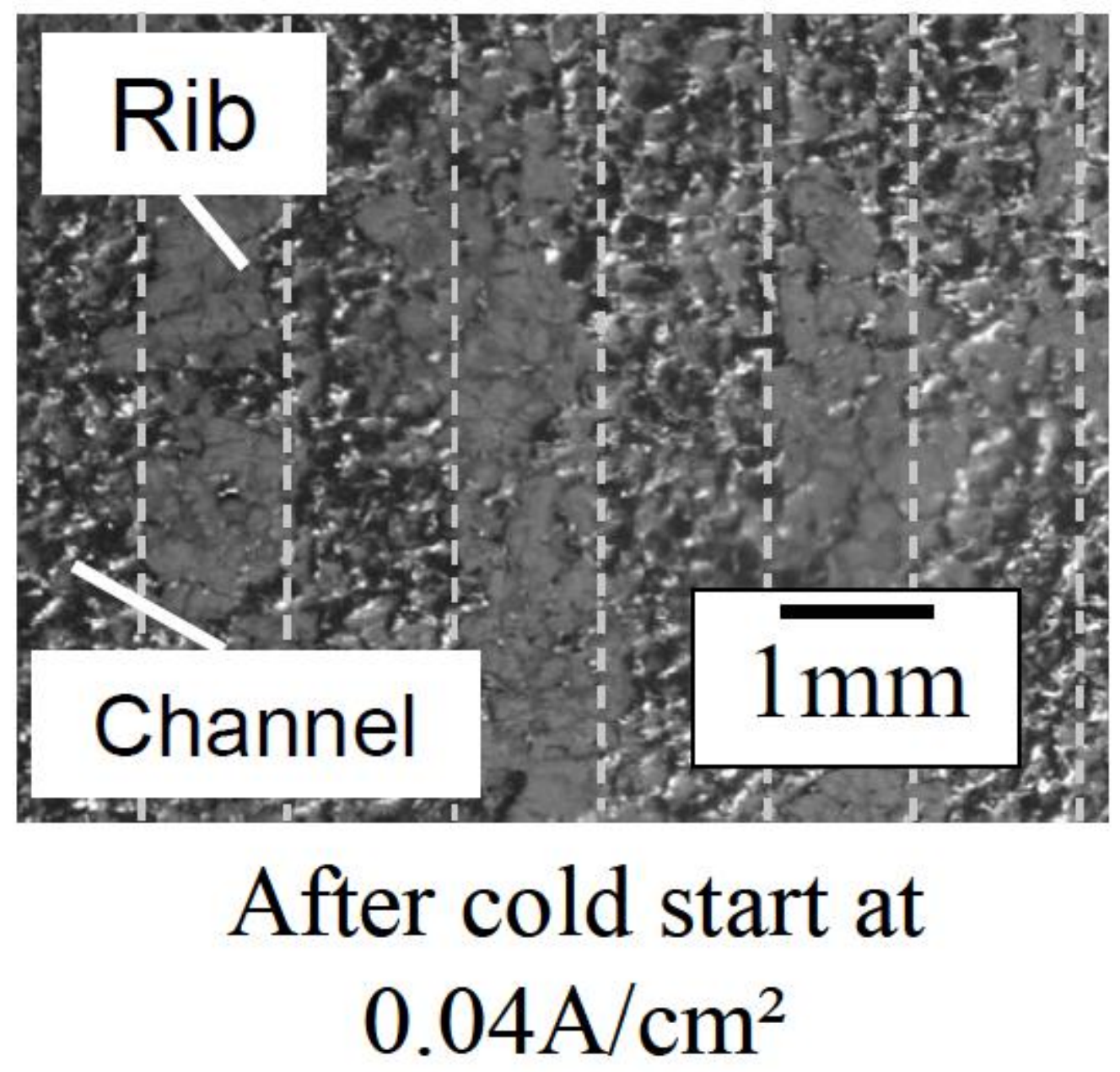

Figure 11 Photos of ice formed on the MEA surface after cold start at $-10^{\circ} \mathrm{C}$; some of the related results are presented in [26] 


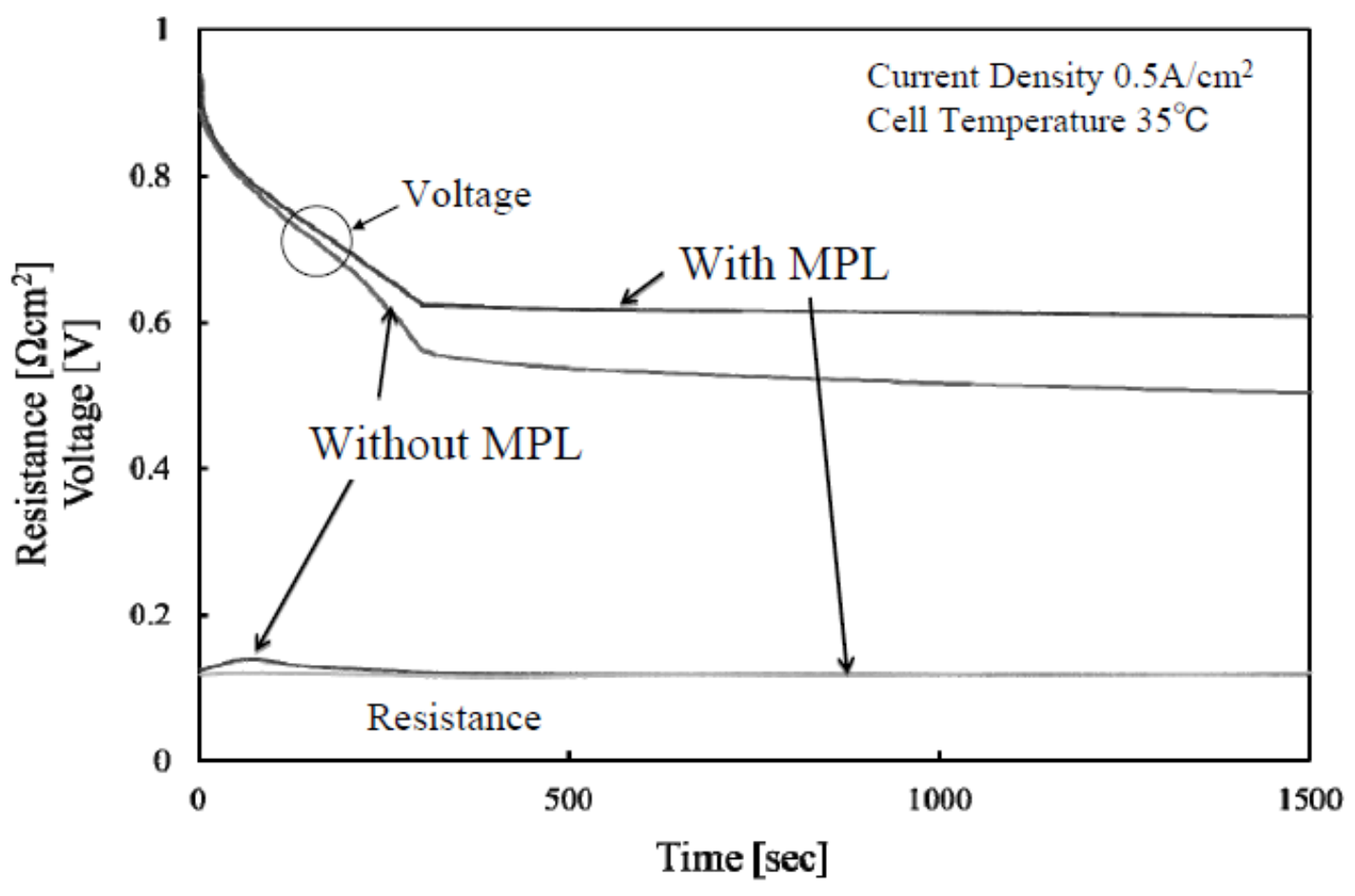

Figure 12 Plot of cell voltages and resistance with and without an MPL; some of the related results are presented in [26] 


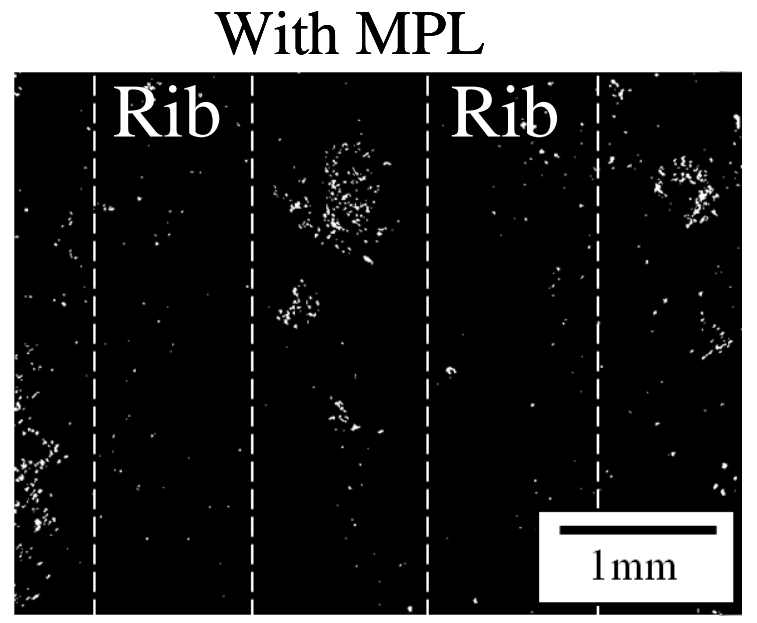

Channel

Averaged ice area

Channel: $1.37 \%$

Rib: $0.92 \%$

MEA: $1.15 \%$

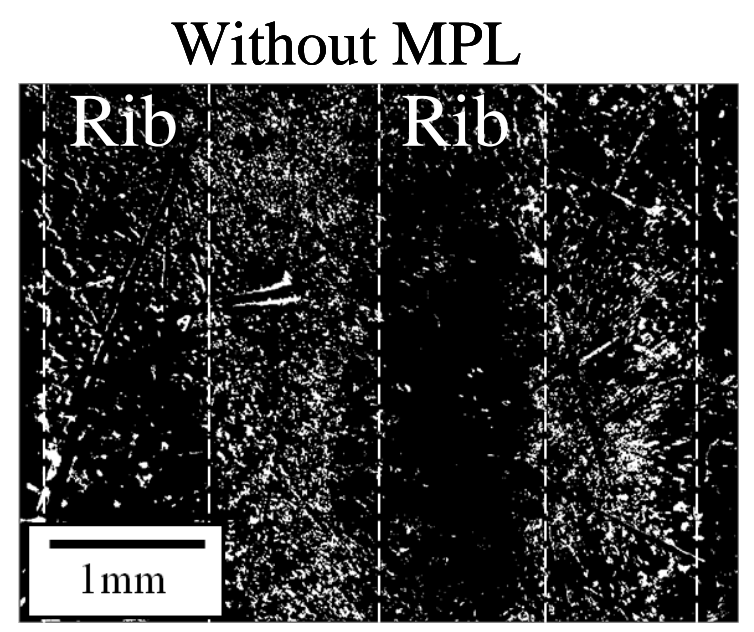

Channel Channel

Averaged ice area

Channel: $14.6 \%$

Rib: $24.9 \%$

MEA: $19.8 \%$

Figure 13 Effect of MPL on the water amount (white) at the interface between the MEA and MPL; the water is observed in the form of ice after freezing at $-30^{\circ} \mathrm{C}$; some of the related results are presented in [26] 


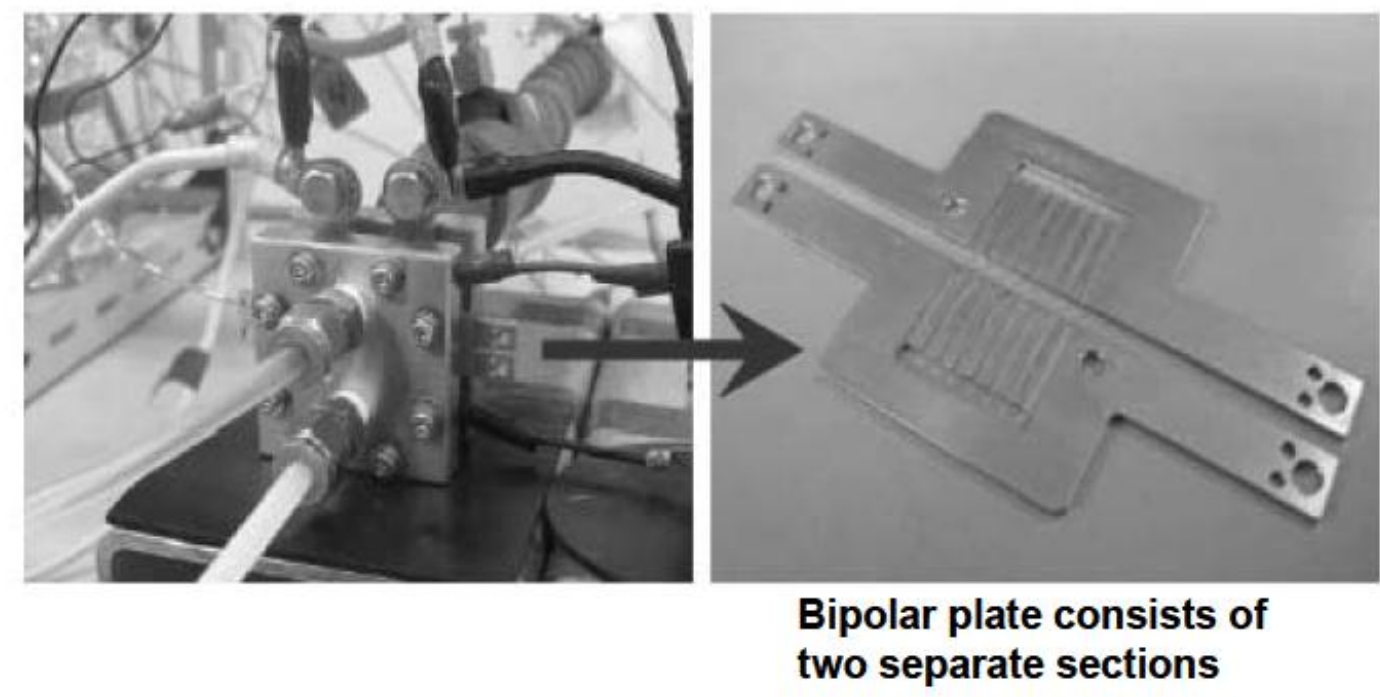

Figure 14 Views of the $2 \mathrm{~cm}^{2}$ active area PEFC for cross-sectional observations of the GDL and MEA, here the bipolar plates consist of two separate sections [2] 

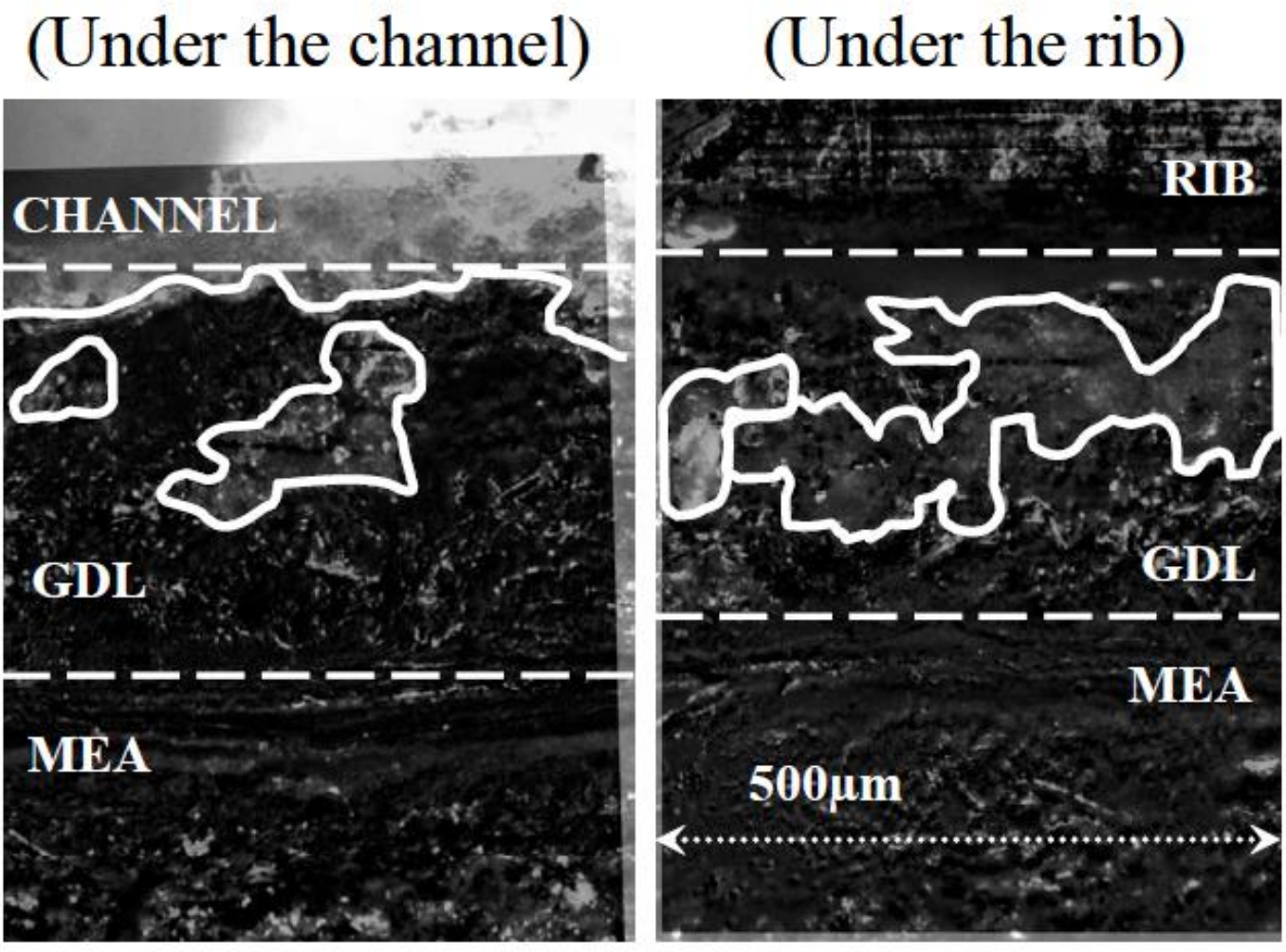

\section{Estimated Average water amount Under the channel $\quad 11 \%$ Under the rib $\quad 17 \%$}

Figure 15 Water in the GDL observed in the form of ice after freezing at $-30^{\circ} \mathrm{C}$ at two locations: under channels and under ribs [2] 


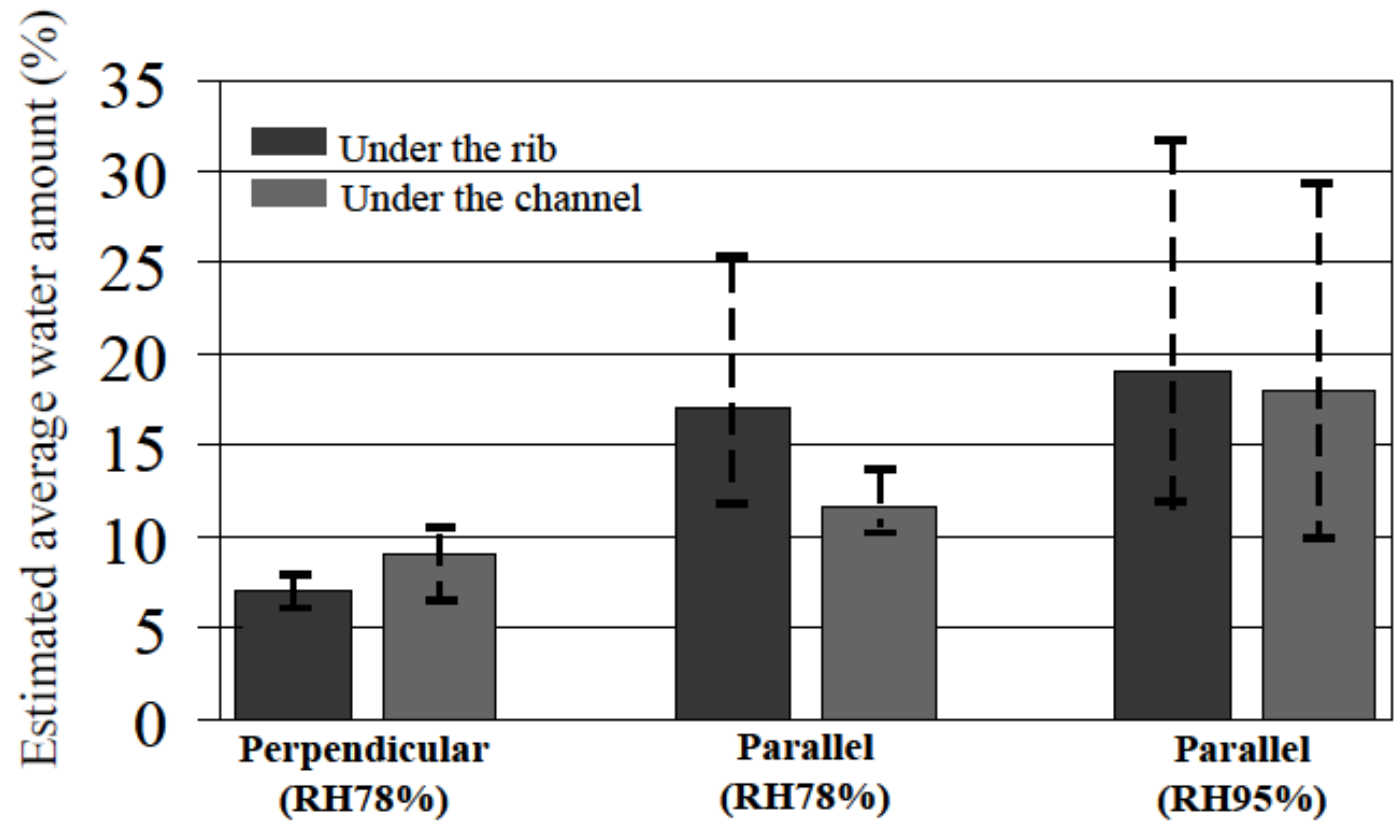

Figure 16 Averaged area percentages of water in the GDL observed in the form of ice after freezing at $-30^{\circ} \mathrm{C}$; for anisotropic GDL fiber directions relative to the channel direction and two relative humidity $(\mathrm{RH})$ conditions [2] 


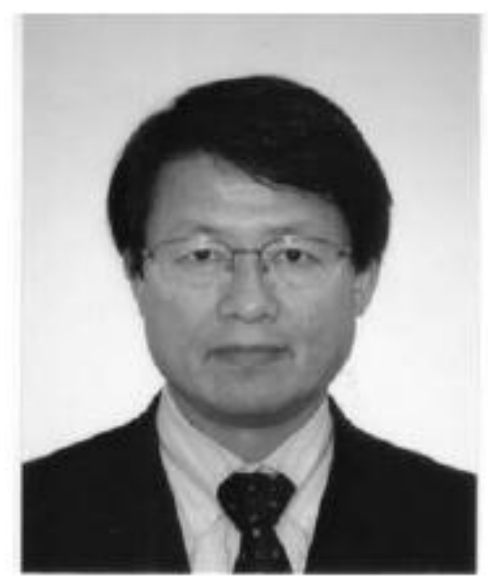

Takemi Chikahisa is a professor at the Division of Energy and Environmental Systems, the Graduate School of Engineering, Hokkaido University, Japan. He received his M.Sc. degree in Mechanical Engineering in 1980 from the University of Wisconsin-Madison, USA, and his Ph. D. in Mechanical Engineering in 1982 from Hokkaido University, Japan. He was originally researching internal combustion engines, and proposed a similarity theory of combustion in diesel engines. Now he has been working on water transport behavior in PEM fuel cells for more than ten years, and trying to establish the optimal design structure of gas channels and gas diffusion layers (GDL) in fuel cells. He is also interested in the analysis of effective strategies for reducing $\mathrm{CO}_{2}$ emissions from countries maintaining employment levels, by the MARKAL model. 